\title{
The State and Church policy in Russia/USSR towards the Buddhist confession
}

\author{
DOI: 10.31551/2410-2725-2018-4-2-253-264
}

\section{Mitupov Victor Mijatovich}

Candidate of Historical Sciences, Doctoral student of The Institute for Mongolian, Buddhist and Tibetan Studies of the Siberian Branch of the Russian Academy of Sciences. Russian Federation, 670000, Ulan-Ude, Victory Avenue, 11-16. E-mail:viktor.mitypov@mail.ru

\begin{abstract}
The article analyzes the State and Church policy towards the Buddhist confession in Russia/USSR and its implementation in the specific conditions of Buryatia. The attitude of the local authorities to the Buddhist confession was determined by the general guidelines of the center for anti-religious struggle and was explained by the search for special forms of application of Soviet legislation on religion and the Church in Buryatia. The paper shows the process of formation of a special model of state management of the religious sphere - the creation of a well-established mechanism of suppression and control of religious organizations by the state.
\end{abstract}

Keywords: Buryat-Mongolian ASSR; Soviet Union; Church-State policy; the Buddhist religion; the laws; the Constitution.

\section{Буддистік конфессияға қатысты Ресей/КСРО мемлекеттік-шіркеулік саясаты}

\section{Митыпов Виктор Мижитович}

тарих ғылымдарының кандидаты, РҒА СБ моңғолтану, буддология және тибетология Институтының докторанты. Ресей Федерациясы, 670000, Улан-Удэ қ, Победа даңғылы, 11-16. E-mail: viktor.mitypov@mail.ru

\begin{abstract}
Аңдатпа. Мақала Ресейде / КСРО-да буддистік сенімге қатысты мемлекеттік-шіркеулік саясатын талдайды және оны Бурятияның нақты жағдайында жүзеге асырады. Жергілікті биліктің Будда дініне деген көзқарасы дінге қарсы күрес жөніндегі орталықтың жалпы басшылығымен анықталды және Бурятиядағы дін және шіркеу туралы кеңестік заңнаманы қолданудың ерекше нысандарын іздеу арқылы түсіндірілді. Құжаттамалық негізде діни саланы мемлекеттік басқарудың арнайы моделін қалыптастыру үдерісі - діни ұйымдарды мемлекет тарапынан басып отыру мен бақылаудың жақсы жұмыс істейтін механизмі көрсетілді.

Кілт сөздер: Бурят-Моңғол АКСР-і; КСРО; мемлекеттік - шіркеулік саясаты; буддистік конфессия; заңнама; Конституция.
\end{abstract}

\section{Государственно-церковная политика в России/СССР в отношении буддийской конфессии}

\section{Митыпов Виктор Мижитович}

кандидат исторических наук, докторант Института монголоведения, буддологии и тибетологии СО РАН. Российская Федерация, 670000, г. Улан-Удэ, пр. Победы, 11-16. E-mail: viktor.mitypov@mail.ru

Аннотация. В статье проанализирована государственно-церковная политика в отношении буддийской конфессии в России/СССР и ее реализация в специфических условиях Бурятии. Отношение местных властей к буддийской конфессии определялось общими установками центра по антирелигиозной борьбе и объяснялась поисками особых форм применения советского законодательства о религии и церкви в Бурятии. На документальной основе показан процесс складывания особой модели государственного управления религиозной сферой - создания отлаженного механизма подавления и контроля религиозных организаций государством.

Ключевые слова: Бурят-Монгольская АССР; СССР; государственно-церковная политика; буддийская конфессия; законодательство; Конституция 


\section{ӘОЖ/ УДК 94+323:2(470)}

\section{Государственно-церковная политика в России/СССР В отношении буддийской конфессии}

\section{B.М. Митыпов}

Как известно, в 1741 г. указом российской императрицы Елизаветы Петровны буддизм в Бурятии был официально признан государственной религией. Однако еще долгое время не было документа, регулирующего правовое положение буддийской церкви, она считалась частью государственного аппарата. В 1853 г. было принято «Положение», основной нормативный акт, регулирующий взаимоотношения церкви и государства и внутрицерковные отношения в буддизме. Была проведена централизация административного аппарата церкви, управление формально было сосредоточено в руках главы буддийской церкви - Бандидо Хамбо-ламы. Несмотря на это, буддизм, как, впрочем, и другие религии, в первую очередь, православие, оставался юридически бесправным и накрепко подчиненным государству.

В конце XIX - начале XX в. фрункционировала выстроенная система церковно-государственных отношений, опиравшихся на законы Российской империи. Под воздействием первой русской революции власть предприняла попытку изменить церковно-государственные отношения: 17 апреля 1905 г. был издан указ Императора Николая II "Об укреплении веротерпимости», расширивший пределы свободы совести, но не уточнивший правовой основы отношений государства и религий. В 1906 г. правительство Столыпина внесло в Думу ряд вероисповедных законов. Среди них были законопроекты об иноверных обществах, а также об отношении государства к отдельным исповеданиям (Об инославных 1907: 541-547). Однако ни один из законо-проектов не стал законом они были заблокированы Госдумой и Госсоветом.

После смены власти в 1917 г. Россия вступила на путь секуляризации, который на начальном этапе приобрел характер насильственной «атеизации» и «преодоления религии». Гражданская война резко изменила политический и правовой статус страны. Все разработанные в 1917-1919 гг. проекты переустройства буддийской церкви так и не обрели силу закона. С 1918 г. начала складываться своеобразная модель государственного управления религиозной ссрерой. Большевики пришли к осознанию того факта, что в системе государственного управления необходимо было иметь центральное учреждение, которое выполняло бы функции государственного надзора, регламентирования религиозных вопросов, в чью компетенцию входило бы разрешение возникавших споров между религиозными обществами как частными лицами и органами государственной и местной власти. Для выполнения этих задач 8 мая 1918 г. декретом СНК при Наркомюсте был образован VIII (впоследствии V) отдел под руководством Л.А. Красикова. Характерно, что культовый отдел был организован при министерстве юстиции, в чьем подчинении находились местные органы - суд и прокуратура.

Декретом от 20 января 1918 г. «Об отделении церкви от государства и школы от церкви» (Законодательство 1971: 68-72) фрормулировались сущность и содержание режима отделения церкви и государства в СССР. В нем предусматривалось отсутствие государственного правового контроля или принужде- 
ния при определении гражданами своего отношения к религии, декларировалось право каждого гражданина исповедовать любую религию или не исповедовать никакой и провозглашалась гарантия полного равенства граждан в правах и обязанностях, независимо от отношения к религии. Эти основные положения были изложены в ст. 2, 3 и 6 Декрета. Подчеркивалось, что Советское государство и его органы не ведут учета граждан по признаку их отношения к религии, официальные документы граждан также не содержат указаний на этот счет (прим. к ст. 3 Декрета).

Против какой бы то ни было регистрации граждан по принципу религиозной принадлежности категорически возражал В.И. Ленин. «Из всех официальных актов всякое указание на религиозную принадлежность граждан устраняется», - писал он в проекте декрета (Ленин 1980: 287-289). Это положение вполне соответствовало нормам демократии. Именно отсутствие регистрации граждан по принципу религиозной принадлежности, исполнения ими религиозных обрядов, гарантирует невозможность дискриминации верующих по религиозным мотивам. И, наоборот, нарушение принципов демократии, свободы совести и отделения церкви от государства проявляется в регистрации.

Согласно ст. 10 Декрета, все церковные и религиозные общества подчинялись общим положениям о частных обществах и союзах и не пользовались никакими преимуществами или субсидиями от государства, местных автономных и самоуправляющихся учреждений. По этому Декрету церковные и религиозные общества не имели права владеть собственностью и перестали являться юридическими лицами. Другим основным положением Декрета являлось провозглашение отделения школы от церкви. В соответствии с этим, не допускалось распространения религиозных вероучений во всех государственных и общественных, а также частных учебных заведениях, где преподаются общеобразовательные предметы. Граждане могли обучать или обучаться частным образом. Декрет «Об отделении церкви от государства и школы от церкви» послужил основой для последующих законодательных актов, определивших взаимоотношение государства и религиозных объединений.

На деле религиозные объединения, по представлению большевиков, являлись единственными легальными организациями, впитавшими в себя все враждебные им элементы. В 1922 г. в законодательных актах советской власти появляется термин «регистрация религиозного общества» (Декрет ВЦИК от 12 июня 1922 г.). Согласно Постановлению ВЦИК от 3 августа 1922 г., ни одно религиозное общество не могло начать свою деятельность без регистрации его в отделе управления губернского или облисполкома. В 1924 г., после издания Конституции РСФСР, вышел циркуляр НКЮ о сохранении силы за циркуляром НКЮ № 254 (10.04.1924 г.), в котором особо подчеркивалось, что религиозные общества, не зарегистрировавшиеся в течение трех месяцев со дня опубликования текста Конституции, являются закрытыми (Законодательство 1971: 98-99).

Сохранялся и принцип регистрации священнослужителей, хотя в п. 54 Постановления «О религиозных объединениях» от 8 апреля 1929 г. это недвусмысленно запрещалось. Кроме того, помимо учредителей религиозного общества, при регистрации нужно было представить наряду с другими документами и список членов регистрируемого общества, т. е. фактически вводилась регистрация граждан по принципу религиозной принадлежности. Противоречивший Конституции принцип «регистрации» являлся прямым вмешательством государства в церковные дела. 
Регистрация религиозных обществ в Бурятии стала проводиться с 1923 г. в соответствии с принятыми в 1922 г. постановлениями ВЦИК и СНК БАМССР. В 1923-1924 гг., в период первых попыток проведения в жизнь Декрета об отделении церкви от государства, среди буддийского духовенства стали возникать земледельческие ламские коммуны в Агинском, Кижингинском, Койморском и некоторых других дацанах. Их возникновение было связано с рекомендацией Наркомюста РСФСР правительству БМАССР «путем наделения лам землей в трудовое пользование создать условия для включения основной массы рядового духовенства в общую трудовую жизнь населения республики» ${ }^{1}$. Такие коммуны подлежали регистрации с утверждением «Устава трудовой общины буддийских монахов». Образование и регистрация религиозных обществ вызвала приток населения в эти общества. Именно по этой причине они просуществовали очень короткий срок.

Политика местных властей по отношению буддийской конфессии определялась общими установками центра по антирелигиозной борьбе. В республике было запрещено поступление в хувараки детям до 18 лет, открытие школ советского типа и врачевание в дацанах. На основании декретов и законодательных актов СНК и решений местных властей крестьянам были переданы дацанские земли, скот и недвижимое имущество.

Такое отношение государства к религии и церкви создавало благоприятные условия для неограниченных репрессивных мер против всего церковного. Задачи подавления религии диктовали и необходимость участия в этом карательных органов. Эту функцию взяли на себя органы НКВД, которые в полном объеме проводили партийную установку - «...мы с религией боролись и боремся понастоящему» (Ленин 1970, Т.44: 146). Особая роль в борьбе «с церковной контрреволюцией» принадлежала VI отделу ОГПУ. На НКВД в отношении религиозных организаций возлагались следующие обязанности: общий надзор за их деятельностью, регистрация (в том числе и уставов) и учет; контроль исполнения Декрета «Об отделении церкви от государства»; выдача разрешений на проведение съездов, пресечение нарушений законодательства. ОГПУ контролировало политическую сторону деятельности духовенства и органов церковного управления (Одинцов 1994: 66, 77).

Вмешательство светских сил в церковную жизнь происходило с первых дней существования советской власти. Законность во взаимоотношениях церкви и государства обеспечивалась тем, что все вопросы, связанные с осуществлением Декрета, были в ведении Народного Комиссариата Юстиции (в лице его V отдела) и решались, согласно Закону. Позднее было решено создать отдельную государственную организацию, ведавшую церковными делами, возглавляемую государственным чиновником. 8 апреля 1929 г. была учреждена Постоянная Центральная Комиссия при Президиуме ВЦИК по вопросам культов, которую возглавил П.Г. Смидович.

Соответствующие комиссии были созданы в республиках и автономных областях. В своей деятельности они руководствовались Постановлением ВЦИК и СНК РСФСР от 8 апреля 1929 г. «О религиозных объединениях». Законодательная политика государства была направлена на подрыв и, в конечном итоге, на ликвидацию буддийской конфессии. Бюро Бурят-Монгольского обкома ВКП(б) 12-13 августа 1929 г. приняло резолюцию «Об антирелигиозной ра-

${ }^{1}$ ГАРБ (Государственный архив Республики Бурятия), ф. 1-П, оп. 1, д. 377, л. 71-74. 
боте», в которой были определены обязанности государственных, партийных, комсомольских и других организаций в этом направлении.

Еще раньше, в 1922 г., на І духовном съезде буддистов двух БурятМонгольских автономных областей ДВР и РСФСР, были приняты проекты «Положения об управлении духовными делами буддистов Сибири» и «Устава внутренней жизни монашествующих в буддийских хидах Сибири», которые должны были заменить устаревшее царское «Положение 1853 года». Первый документ устанавливал систему административного управления ламаистской церкви Бурятии, второй - правила внутреннего распорядка монастырей и правила жизни монашеской общины.

Фактически же буддийское духовенство ставилось в положение, когда его деятельность должна была регулироваться не каноническими положениями монастырского устава, но решениями «активистов» из мирян, которые по предложенному проекту легко могли получать большинство в приходских советах. Этим не только решалась актуальная для новой власти проблема контроля над духовенством, но и в значительной степени ослаблялось влияние ламства на мирян, поскольку возможности духовенства влиять на принятие решений резко ограничивались.

В 1924 г. была создана Комиссия по вопросам религиозных культов при ВЦИК РСФСР. Одновременно при губернских, областных и городских Советах были организованы Комиссии по вопросам религиозных культов. В их компетенцию входило распространение и разъяснение нормативных актов, касающихся церковно-религиозной сферы, консультации районным и поселковым Советам по вопросам учета, регистрации и налогообложению религиозных обществ и служителей культа, а также предварительное рассмотрение дел о постройке, открытии или закрытии молитвенных зданий - дацанов, дуганов. Районные исполнительные и поселковые Советы не могли без ведома вышестоящих культовых комиссий производить какие-либо действия в этой сфере. Кроме того, культовые комиссии должны были разрешать споры, которые могли возникнуть между религиозными обществами и местными органами власти, и разбираться с жалобами служителей культа.

Однако на практике процветало повсеместное самоуправство местных органов власти, особенно в области ликвидации или использования культовых зданий. В решении вопросов церковно-религиозной политики на местах главную роль играли районные исполнительные комитеты и поселковые советы. Эта ситуация вытекала из того, что функции регистрации религиозных обществ и решение по конкретным культовым просьбам верующих находились целиком в компетенции общих отделов РИКов - органов системы НКВД.

Декрет об отделении церкви от государства и школы от церкви был принят в БМАССР 17 декабря 1925 г. Эта задержка объяснялась поисками особых форм применения советского законодательства РСФСР о религии и церкви в специфических условиях Бурятии. В связи с проведением Декрета в жизнь Бурят-Монгольский обком партии на заседании от 10 февраля 1926 г. поручил Совнаркому республики: 1. «уничтожить право собственности и право юридического лица религиозных обществ и организаций; 2. идти к уничтожению всяких принудительных сборов, собираемых этими организациями и отдельными лицами; 3. к прекращению участия духовных лиц в воспитании и образовании 
молодежи; 4. создать гарантию недопущения светского образования в религиозных школах и, наоборот, религиозного образования в светских школах» ${ }^{2}$

В 1925 г. в БМАССР для осуществления контроля и определения политики в отношении всех религиозных объединений республики, а также введения антирелигиозной пропаганды при Буробкоме РКП(б) была создана Комиссия по религиозным вопросам. Она была утверждена постановлением бюро обкома РКП(б) от 8 декабря 1925 г. В состав комиссии вошли секретарь и заведующий агитационно-пропагандистским отделом РКП(б), председатель областной контрольной комиссии РКП(б), председатель Совнаркома и начальник областного отделения ОГПУ с кандидатами в члены - их заместителями по должности. Основными задачами комиссии были проработка, руководство и контроль за всеми мероприятиями по осуществлению Декрета об отделении церкви от государства. Комиссия также занималась разработкой мероприятий по ликвидации религиозного, политического и экономического влияния на верующих всех вероисповеданий, научной проработкой вопросов религиозного культа, составлением тезисов отчетов, докладов, диаграмм, изысканием средств на расходы, связанные с работой комиссии. 25 декабря 1925 г. постановлением бюро обкома РКП(б) учреждаются аналогичные комиссии по религиозным вопросам при аймачных комитетах в составе секретаря айкома РКП(б), председателя аймисполкома и уполномоченного областного отдела ОГПУ. Созданные комиссии явились главными органами, определяющими основные направления антирелигиозной борьбы (Цыремпилова 2000: 87-88).

В связи с принятием Декрета в 1925-1927 гг. в буддийской конфессии обострилась борьба между обновленцами и консерваторами, в основе которой было не только отношение к советской власти, но и модернизация религиозных догматов, стремление приспособить религию к изменившейся идеологии. Эта борьба завершилась на Всесоюзном духовном соборе буддистов в июне 1927 г. победой обновленцев.

В законодательных актах БМАССР решались вопросы об избирательных правах, призыве лам на военную службу и о правах лам на землепользование. Показательна инструкция ЦИК БМАССР от 10 августа 1928 г. по проведению комбинированной системы мероприятий на местах. В ней предусматривались экономические ограничения ламства в форме подоходного налога, военного налога, сбора с лам, не имеющих права быть сомонными исполнителями, самообложения, сельхозналога, лесного сбора, арендной платы за дацанские земли и т.д. Таким комплексом мер государства подрывалось экономическое положение буддийской церкви.

Одной из составляющих политики власти в антирелигиозной борьбе была организация Союза воинствующих безбожников (СВБ). Областной союз был организован в Верхнеудинске 2 декабря 1926 г. Своей задачей он ставил объединение всех трудящихся для организации активной борьбы против религии во всех ее видах и формах. Официально устав областного союза безбожников был зарегистрирован в Центральном Совете СВБ 27 января 1927 г., а 29 января 1927 г. утвержден НКВД Бурреспублики ${ }^{3}$. В 1930-е гг. СВБ сыграл особую роль в процессе усиления борьбы с религией. В 1929 г. Комиссия по вопросам религиозных культов при ВЦИК РСФСР была преобразована в Постоянную Комиссию при ВЦИК РСФСР. В ее компетенцию входили: разработка и пред-

\footnotetext{
${ }^{2}$ ГАРБ, ф. 1-п, оп. 1, д. 657, л. 52.

${ }^{3}$ ГАРБ, ф. Р-581, оп. 1 , д. 4 , л. 2.
} 
варительное рассмотрение проектов постановлений по вопросам, связанным с деятельностью религиозных объединений. Ведомственные учреждения должны были согласовывать свои действия по религиозным вопросам с Комиссией. На Комиссию была возложена обязанность по рассмотрению жалоб граждан, ведение учета религиозных организаций. Сама Комиссия действовала до 1934 г. не в общесоюзном, а в республиканском масштабе.

В 1934-1938 гг. в Бурятии был принят ряд постановлений ЦИК, СНК БМАССР и обкома ВКП(б) об ужесточении налогообложения и постепенном запрещении деятельности лам. В начале советизации российского общества священники объявлялись «классово чуждыми элементами» и лишались продовольственных карточек, дети «классовых врагов» не могли учиться в ВУЗах страны социализма. «С подготовкой нового поколения трудящейся молодежи в советской школе, интернатах и ВУЗах, в том числе в Комвузе в г. Москве, «чуждые элементы» перешли в разряд «классовых врагов», с которыми советская власть призывала бороться, как с «внутренним врагом», путем разрушения храмов, монастырей всех конфессий, расстрелом представителей церкви, заключением с конфискацией имущества и ссылкой на каторжные работы» (Цыремпилова 2000: 138).

Ситуация в церковно-государственных отношениях в 1920-1930-х гг. характеризовалась существованием «двойного» законодательства в церковнорелигиозных вопросах. Негласно, но последовательно проводившаяся политика регистрационного и налогового гнета приводила к изоляции религиозных конфессий в советском обществе и внутреннему их истощению. В Бурятии был принят ряд постановлений ЦИК, СНК БМАССР и обкома ВКП(б) об ужесточении налогообложения и постепенного запрещения деятельности буддийского духовенства.

В 1937 г. во время репрессий и борьбы с «врагами народа» была предпринята попытка и вовсе ликвидировать законодательство о культах. В 1938 г. была ликвидирована культовая Комиссия при ЦИК СССР. С 1938 по 1943 г. единственной организационной структурой, занимавшейся церковной политикой, являлся специальный отдел, существовавший в недрах госбезопасности.

Наряду с закрытием дацанов и дуганов органами НКВД, проводились карательные мероприятия против лам. Священнослужители обвинялись в шпионаже, различных диверсиях и вредительской работе в колхозах и совхозах. В конечном итоге антирелигиозная компания привела к полному уничтожению буддийской конфессии Бурятии. К 1940 г. в республике не осталось ни одного действующего дацана. Все 46 дацанов и дуганов были разрушены.

После образования в сентябре 1943 г. Совета по делам Русской православной церкви при СНК СССР был создан Совет по делам религиозных культов при СНК СССР. Основными задачами этих органов являлось осуществление связи между правительством СССР и руководителями религиозных центров, внесение на рассмотрение правительства проектов законодательных актов, касающихся религиозных организаций, наблюдение за правильным проведением в жизнь законов о культах и информация правительства о деятельности религиозных организаций в стране.

За годы советской власти был создан отлаженный механизм подавления и контроля религиозных организаций государством, причем государство брало на себя и ряд чисто внутрицерковных функций. Социалистическое государство стало активнее использовать в интересах государства отдельные религиозные 
конфессии. Такой поворот имел веские основания. С началом Великой Отечественной войны церковь заняла активную патриотическую позицию. Представители бурятского духовенства принимали участие в сборе денежных средств в Фонд обороны, оказывали религиозную помощь семьям, потерявшим своих близких на фронтах войны.

В информационном докладе уполномоченного Совета по делам религиозных культов при Совнаркоме СССР по БМАССР Н.Г. Гармаева Председателю Совета Д.С. Полянскому отмечалось: «Религиозно-патриотическое движение в республике развертывается только среди верующих-буддистов, оно имеет форму сбора средств в Фонд обороны. За первый квартал 1945 г., по данным республиканской конторы Госбанка, поступило от верующих-буддистов в фонд обороны всего в сумме 150 тыс. руб. Отдельные лидеры ламства, как Галсанов Хайдап (дид хамбо) с начала кампании собрал и сдал в Госбанк 90 тыс. руб. и получил благодарность от тов. Сталина; Дармаев Лобсан-Нима, он внес 34 тыс. руб. и Тасорунов Чагдур - 60 тыс. руб. Поступление средств продолжается» ${ }^{4}$. Личной благодарностью И.В. Сталина и других деятелей партии была отмечена и деятельность других бурятских лам.

В годы Великой Отечественной войны произошел, по сути, возврат к старой, дореволюционной модели контроля государства за религиозными конфессиями, но в рамках социалистического государства. Не имея опыта самостоятельного функционирования, российские религиозные конфессии в обмен на поддержку государства и сохранение статус-кво поддержали своим авторитетом государственную власть. Это в полной мере относилось и к буддизму.

Постановление СНК СССР за № 1603 от 19 ноября 1944 г. дало начало в послевоенные годы процессу восстановления религиозных организаций в СССР. На его основании СНК Бурят-Монгольской АССР приняло постановление «О порядке открытия молитвенных зданий религиозных культов» (№ 186-ж от 3 мая 1945 г.), по которому было удовлетворено ходатайство верующих об открытии буддийского храма «Хамбинское Сумэ» в улусе Средняя Иволга. В мае 1946 г. в Улан-Удэ состоялся съезд представителей духовенства и верующих мирян из БМАССР, Читинской, Иркутской областей и Тувинской автономной области, на котором было обсуждено и утверждено «Положение о буддийском духовенстве в СССР», избрано Временное Центральное духовное управление буддистов (ВЦДУБ) ${ }^{5}$. Хотя еще в мае 1945 г. Совет по делам религиозных культов при СНК СССР принял решение восстановить Центральное духовное управление буддистов для руководства религиозными делами общины и проведения через нее «отдельных мероприятий религиозно-патриотического движения», а также для «борьбы с нелегальными молебствиями» ${ }^{6}$. «оложение о буддийском духовенстве» основывалось на уставе обновленческого движения бурятского духовенства 1920-1930 гг., ставившего задачу, приспособить буддийскую церковь к общественному и политическому строю социалистического государства.

Восстановление буддизма в России в послевоенные годы было сопряжено с возникшими трудностями. С середины 1950-х гг. усилилась антирелигиозная и атеистическая пропаганда, в связи с тем, что «церковь и различные религиозные секты значительно оживили свою деятельность, укрепили свои кадры и,

\footnotetext{
${ }^{4}$ ГАРБ, ф. Р-248, оп. 4 , д. 68, л. 10.

${ }^{5}$ ГАРБ, ф. 248 , оп. 4 , д. 71 , л. 93.

${ }^{6}$ ГАРБ, ф. Р-248, оп. 4, д. 68, л. 8a-11.
} 
гибко приспосабливаясь к... условиям, усиленно распространяют религиозную идеологию среди отсталых слоев населения» (Одинцов 1991: 20). Все то положительное, что было достигнуто в государственно-церковных отношениях, начиная с 1943 г., было объявлено деформацией «церковной политики» социалистического государства и «неправильной политической и тактической линией, приведшей к укреплению религии и церкви», способствовавшей созданию благоприятных условий для пропаганды «реакционной идеологии для деятельности многочисленных врагов среди духовенства». В начале 1960-х гг. сложилось понимание места и роли атеизма в советском обществе в качестве главного рычага формирования научно-материалистического мировоззрения. «Общество без религии» объявлялось программной целью на ближайшую перспективу.

Основная работа по осуществлению контроля над ЦДУБ возлагалась на уполномоченных Совета, которые периодически должны были отчитываться о его деятельности в Совете по религиозным культам, преобразованном в 1965 г. в Совет по делам религий при Совмине СССР. Культовые, кадровые, хозяйственные, строительные, финансовые проблемы ЦДУБ согласовывались с Советом и уполномоченными. Государство продолжало использовать буддийскую церковь в целях поддержки интересов социалистического лагеря и СССР на международной арене. Одним из наиболее авторитетных лам, выделявшихся ученостью и человеческими качествами, имевших опыт международной деятельности, был Ж.-Д. Гомбоев. В 1963 г. после смерти Е.-Д. Шарапова он был избран Бандидо Хамбо ламой. Как следовало из докладной записки уполномоченного по делам религиозных культов при Совмине БурАССР Д.Б. Очиржапова председателю Совета по делам религиозных культов при Совмине СССР А.А. Пузину о результатах выборов нового председателя ЦДУБ СССР, «Гомбоев Жамбал-Доржи, 1896 г. рождения, уроженец Агинского бурятского национального округа Читинской области, имеет высшее духовное образование (с 1908 по 1933 гг. служил в Агинском дацане), хорошо владеет бурятским и русским языками, участник Великой Отечественной войны, был дважды ранен и награжден медалью «За отвагу», к советской власти лоялен, дисциплинирован. В 1956 г. был избран заместителем председателя ЦДУБ и настоятелем Агинского дацана, с этого времени принимает активное участие в жизни ЦДУБ и вверенного ему дацана. Он неоднократно бывал за границей в составе делегации буддистов, где участвовал в различных международных конференциях буддистов и сторонников мира, встречался с главами правительств стран ЮгоВостока Азии, а также принимал участие в сопровождении иностранных буддийских делегаций по Советскому Союзу. Будучи за границей, представлял нашу страну достойно» (Из истории... 2001: 188). При Бандидо Хамбо ламе Ж.-Д. Гомбоеве возрос международный авторитет Центрального Духовного Управления буддистов: в 1972 г. он был избран вице-президентом Всемирного Братства Буддистов. Им также многое было сделано для разрешения внутренних проблем буддийской церкви.

Как известно, Постановление ВЦИК и СНК РСФСР от 8 апреля 1929 г. «О религиозных объединениях», по существу, определило на долгие годы положение и права религиозных организаций в СССР (до конца 1980-х гг.). Указом Президиума Верховного Совета РСФСР от 23 июня 1975 г. в него были внесены изменения и дополнения. При этом право государственных органов удалять из исполнительного совета религиозного объединения того или иного челове- 
ка, а также прежние ограничения церковной деятельности остались без изменений, запутанной оставалась процедура регистрации религиозного объединения или открытия молитвенного дома. К позитивным моментам этого постановления можно отнести изменения, приближавшие церковь к статусу юридического лица и упразднявшие положения, которые регламентировали порядок выборов делегатов на высшие собрания религиозного объединения.

Не были решены вопросы регистрации новых лам, выезда лам в районы для исполнения духовных треб верующих, не четко определены сроки полномочий выборных органов буддийской конфесссии и т.д. Необходимость уточнения отдельных статей и дополнений «Положения о буддистском духовенстве в СССР» стала поводом к созыву 9 марта 1969 г. VI съезда ЦДУБ, на котором были приняты новые «Положение о буддистском духовенстве» и Устав. «Положение 1969 г.» обосновало новое направление в деятельности буддийского духовенства и церкви - международную деятельность ЦДУБ. Международная экуменическая деятельность ЦДУБ стала одним из инструментов улучшения и установления международных дипломатических отношений СССР с государствами Юго-Восточной Азии.

В 1975-1978 гг. в законодательство о религиозных культах союзных республик был внесен ряд изменений, облегчающих положение верующих и религиозных организаций. Конституция 1977 г. по-новому сформулировала понятие о свободе совести. Ст. 52 Конституции гласила: «Гражданам СССР гарантируется свобода совести, то есть право исповедовать любую религию или не исповедовать никакой, отправлять религиозные культы или вести атеистическую пропаганду. Возбуждение вражды и ненависти в связи с религиозными верованиями запрещается. Церковь в СССР отделена от государства и школа - от церкви» (Конституция СССР 1977: 123).

Эта статья, по сравнению со ст. 24 Конституции СССР 1936 г., имела ряд новых положений. Впервые свобода совести была конституционно гарантирована вместо прежних фрормулировок «признается за всеми гражданами», и эта свобода определялась как личное право гражданина. Новым в фоорулировке статьи было и употребление термина «атеистическая» вместо «антирелигиозная» пропаганда. Были введены новые положения о запрещении вражды и ненависти в связи с религиозными верованиями. Но, несмотря на то, что в «Конституции СССР» 1977 г. был подтвержден принцип свободы совести, однако, в реальной жизни продолжала действовать политика «запретительства» в отношении религии вплоть до 1990-х гг. Церковь была лишена статуса общественной организации. Ст. 51 гласила, что «граждане СССР имеют право объединяться в общественные организации», или эти организации создаются «в соответствии с целями коммунистического строительства» (Там же). Если общественная организация не соответствует этим целям, то это право ей не обеспечивается. Следовательно, по ст. 51 Конституции, религиозные организации не пользуются правом общественных организаций, а другой промежуточной альтернативы общественным организациям быть не могло, и, по юридической логике, религиозные организации попадали в категорию «антиобщественных». При этом советское право не знало никакого другого юридического статуса для легального сообщества людей и, следовательно, Церковь фрактически не существовала как субъект права. Из этого вытекало, что религиозные организации не имели прав юридического лица, так как, согласно ст. 24 Гражданского кодекса РСФСР, юридическими лицами являлись государственные предпри- 
ятия, государственные организации, колхозы и общественные организации. Церковь во взаимоотношениях с государством предстает просто частным лицом. Ст. 100 дает право всем общественным организациям выдвигать кандидатов в депутаты, а поскольку Церковь не является общественной организацией, то верующие ограничиваются в своих политических правах, что являлось грубым нарушением основных международно-правовых принципов в этой сфере. Результатом является то, что политические интересы верующих во всех выборных органах власти представляют неверующие.

По существу, Конституция 1977 г. ничего не изменила в правовом положении религии в СССР. В ней не были отражены важнейшие международноправовые принципы. В Уголовном кодексе РСФСР существовали специальные статьи, карающие за нарушение законодательства о культах. Ст. 142 карала за нарушение законов об отделении церкви от государства и школы от церкви. Ст. 227 была посвящена посягательству на личность и права граждан под видом исполнения религиозных обрядов. По своему содержанию эта статья была направлена против руководителей религиозных организаций, выходящих за пределы того, что разрешено законодательством о культах. Формулировки статьи о том, что «карается деятельность, проводимая под видом проповедования религиозных обрядов, сопряженная с причинением вреда здоровью граждан или с иными посягательствами на личность и права граждан, либо с побуждением граждан к отказу от общественной деятельности или исполнения гражданских обязанностей и вовлечением в эту группу несовершеннолетних», можно легко подвести под повседневную работу священнослужителей. То, что ст. 227 в Кодексе находится в одном ряду со ст. 226 (содержание притонов разврата), 228 (изготовление и сбыт порнографических предметов) показывает, на каком уровне должна была находиться религия.

Таким образом, в СССР в законодательном порядке был закреплен ряд положений, резко суживающих право на свободу совести и вероисповеданий в ее международно-правовом аспекте. Те положения, которые были декларированы, на практике не действовали, так как в большинстве своем не являлись правовыми нормами прямого действия. Тем не менее, произошедший в 1943 г. перелом в церковно-государственных отношениях явился началом постепенного перехода к взаимодействию государства и буддийской церкви сначала в плане участия в международных религиозных мероприятиях, а к последней четверти XX в. - к возрождению буддизма в стране.

\section{Әдебиеттер тізімі / Список литературы}

1. Законодательство о религиозных культах. Сб. матер. и док. - М., 1981. - 210 с.

2. Из истории религиозных конфессий Бурятии. XX век. Сб. док. - Улан-Удэ: Комитет по делам архивов, 2001. - $260 \mathrm{c.}$

3. Конституция (основной закон) Союза Советских Социалистических Республик. - М.: Политиздат, 1977.

4. Ленин В.И. К четырехлетней годовщине Октябрьской революции // Полн. собр. соч. Т. 44. М.: Изд-во полит. литературы, 1970. - С. 144-152.

5. Ленин В.И. Об атеизме, религии и церкви: (Сб. произведений, писем и других материалов). 2 е изд., доп. - М.: Мысль, 1980. - 410 с.

6. Об инославных и иноверных религиозных обществах: Законопроект, внесенный МВД России в Государственную Думу // Государственная Дума. Второй созыв. Обзор деятельности комиссий и отделов. - СПб., 1907. - С. 541-547.

7. Одинцов М.И. Государственно-церковные отношения в истории советского общества // Peлигия, общество и государство в XX в.: Матер. науч. конф. - М., 1991.- С. 51-57. 
8. Одинцов М.И. Государство и церковь в России. XX век. - М., 1994. - 171 с.

9. Цыремпилова И.С. Религия и власть в Республике Бурятия: история взаимоотношений (19171940 гг.). - Улан-Удэ: ИПК ВСГАКИ, 2000. - 162 с.

\section{Reference}

Constitution USSR 1977 - Constituciya (osnovnoj zakon) Soyuza Sovetskix Socialisticheskix Respublik 1977, Politizdat, Moscow. (Constitution (basic law) of the Union of Soviet Socialist Republics 1977, Politizdat, Moscow) (in Rus).

Iz istorii religiozny`x $2001-$ Iz istorii religiozny $x$ konfessij Buryatii. XX vek: Sb. Dok, Komitet po delam arxivov, Ulan-Ude', $260 \mathrm{~s}$. (From the history of religious denominations in Buryatia. Of the twentieth century: Sat. Doc, Committee on archives, Ulan-Ude', 260 p). (in Rus).

Lenin 1970 - Lenin, VI 1970, K chety'rexletnej godovshhine Oktyabr'skoj revolyucii, Poln. sobr. soch., T. 44, Izd-vo polit. literatury', Moscow, S. 144-152. (Lenin, VI 1970, to the four-year anniversary of the October revolution, complete works, T. 44, Izd-vo polit. literatury', Moscow, S. 144-152). (in Rus).

Lenin 1980 Lenin, VI 1980, Ob ateizme, religii i cerkvi: (Sb. proizvedenij, pisem i drugix materialov), 2-e izd., dop, My`sl', Moscow, 410 s. (Lenin, VI 1980, About atheism, religion and Church: (Sat. works, letters and other materials), 2nd ed, My`s`', Moscow, 410 p). (in Rus).

Ob inoslavny`x 1907 - Ob inoslavny`x i inoverny`x religiozny`x obshhestvax: Zakonoproekt, vnesenny j MVD Rossii v Gosudarstvennuyu Dumu, Gosudarstvennaya Duma. Vtoroj sozy v. Obzor deyatel'nosti komissij i otdelov 1907, Saint-Petersburg, S. 541-547. (On non-Orthodox and nonOrthodox religious societies: the Bill submitted by the Ministry of internal Affairs of Russia to the State Duma, State Duma. Second convocation. Review of commissions and divisions 1907, SaintPetersburg, S. 541-547). (in Rus).

Odinczov 1994 - Odinczov, Ml 1994, Gosudarstvo i cerkov` $v$ Rossii. XX vek, Moscow, 171 s. (Odinczov, Ml 1994, The state and the Church in Russia. Of the twentieth century, Moscow, $171 \mathrm{p})$. (in Rus).

Odinczov 1991 - Odinczov, MI 1991, Gosudarstvenno-cerkovny`e otnosheniya v istorii sovetskogo obshhestva, Religiya, obshhestvo $i$ gosudarstvo $v \quad X X \quad v$.: Mater. nauch. konf., Moscow, 1991, P. 51-57. (Odinczov, Ml 1991, State-Church relations in the history of Soviet society, Religion, society and the state in the XX century: Mater. scientific. Conf., Moscow, 1991, P. 51-57). (in Rus).

Tsyrempilova 2000 - Tsyrempilova, IS 2000, Religiya $i$ vlast $v$ Respublike Buryatiya: istoriya vzaimootnoshenij (1917-1940 gg.), IPK VSGAKI, Ulan-Ude`, 162 s. (Cyrempilova, IS 2000, Religion and power in the Republic of Buryatia: history of relations (1917-1940), IPK VSGAKI, UlanUde', 162 p). (in Rus).

Zakonodatel'stvo o religiozny 1981 - Zakonodatel'stvo o religiozny`x kul'tax: Sb. mater. i dok 1981, Moscow, 210 s. (Legislation on religious cults. Sat. mater. and doc 1981, Moscow, 210 p). (in Rus). 